Article

\title{
Teaching Dante in the History of Christian Theology
}

\author{
Bryan J. Whitfield 1 \\ Department of Religion, Mercer University, 1501 Mercer University Drive, Macon, GA 31201, USA; \\ whitfield_bj@mercer.edu
}

Received: 20 March 2019; Accepted: 5 June 2019; Published: 7 June 2019

\begin{abstract}
Outside of core curriculum programs or Great Books classes, few undergraduates who are not literature majors read and discuss Dante's Divine Comedy. This paper describes the redesign of a course in the history of Christian theology as a model for integrating the study of Dante into additional contexts within general education. Reading Dante not only as poet but also as theologian can enhance students' learning and their engagement with medieval theology. A focused reading of Paradiso provides a novel and exciting way for a survey course in historical theology to balance general education's needs for both breadth and depth. At the same time, reading Dante also helps students to experience the significant intersections of culture and theology in the medieval period.
\end{abstract}

Keywords: Dante; pedagogy; history of theology; core and general education curricula; interdisciplinarity; medieval theology; literary studies

\section{Introduction}

With respect to Dante, I was one of the lucky ones. As a college sophomore, I stumbled into an introductory literature course where the Inferno was the climax of the treatment of the hero's journey traced through Homer and Virgil to Dante. That class led me to become a comparative literature major and to enroll in an upper-level course on medieval narrative where I read the Paradiso. But most undergraduates in the early twenty-first century are not so blessed. Few have multiple opportunities to read and discuss the Commedia.

My current teaching context is a case in point. The college has two general education tracks. In the Great Books track, students read the Commedia in its entirety during the spring of their sophomore year. But in the more traditional distributional track that comprises nearly ninety percent of the student population, there are no general education courses where students read Dante. What is more surprising is that the Commedia appears on only one other reading list for a course in the college.

If my context is representative, it suggests that those of us who value Dante's central contribution to the Christian and Western intellectual traditions must be intentional about creating space for students to read the Commedia. This paper sketches my initial attempt to teach Dante within the context of a distributional general education program. I offer it as a model for integrating Dante into a discipline-specific course, reflecting on my institutional context, weighing Dante's role as a theologian, and outlining elements of course design and objectives before suggesting some strategies for teaching Dante across the curriculum.

\section{Finding Spaces in an Institutional Context}

Within our college's distributional track, students take one course from several options in the area of Western Heritage. These courses span several departments, including history, philosophy, English, classics, and religion. Religion 270, History of Christian Theology, is one course among these options. The catalogue describes this course as a "study of the ways Christian theology both 
shapes and is shaped by developments in Western culture from the rise of Christianity through the contemporary era."

Any instructor offering this undergraduate "History of Christian Theology" faces significant challenges. Primary among these is the course's span: "the rise of Christianity through the contemporary era." That long arc poses an inevitable tension between breadth and depth. Given this description, the typical course offering focuses on medieval theology for three to four weeks. Students normally read chapters from a secondary text on the history of Christian thought as well as primary texts. In recent years, instructors have used as secondary texts Alister McGrath's Historical Theology or Justo Gonzalez's A History of Christian Thought: In One Volume, along with primary readings from either McGrath's accompanying reader or Hugh Kerr's Readings in Christian Thought (McGrath 2013; Gonzalez 2014; McGrath 2016; Kerr 1990). These primary text selections may include readings from Anselm, Abelard, Bernard of Clairvaux, Peter Lombard, Thomas Aquinas, Duns Scotus, William Ockham, Catherine of Siena, Julian of Norwich, and Thomas à Kempis. Given this welter of names and related theological topics, the instructor's challenge is to find ways to help students to understand both the larger picture of medieval theology and the development of theology across time.

A second challenge arising from the stated goal is that the course will explore the ways theology and Western culture interact. This exploration is particularly significant for the medieval period. Christian theology distinctively shapes the medieval world of Christendom. As such, it provides the paradigmatic example of the interaction of theology and culture in the West. Any effective study of the medieval period requires students to integrate insights from several disciplines, so successful students of the period must bring together theological and philosophical reading with insights from the arts, agriculture, politics, and economic life.

Given these challenges, I argue that Dante deserves consideration as a medieval theologian. Redesigning this course so that students read Dante's Paradiso for a month as their common primary reading provides a novel and exciting response to both challenges, as it balances breadth and depth while addressing the interaction of culture and theology. A guided reading of the Paradiso as theology provides an innovative and creative design for teaching the history of medieval theology that can enhance students' learning and engagement.

\section{Considering Dante as Theologian}

Some faculty and students may object at the outset to such a project, arguing that Dante belongs in a literature course but not a course in theology. Before exploring course design in detail, therefore, I offer a brief rationale for Dante's inclusion in this course with a consideration of Dante as theologian.

Specialists continue to debate whether the Commedia is "theology". Zygmunt Baranski, for example, concludes that in terms of philology, it is inaccurate to label Dante as a theologian or his work as theology (Baranski 2013a, 2013b). Yet, as Vittorio Montemaggi argues, even Baranski's own work shows both that Dante intended for his poem to effect spiritual change in his readers' lives and that he was in line with prevailing theological currents (Montemaggi 2016, p. 62). Dante does not align himself with a particular theological school, since he is aware the divine mystery tempers all human conceptualization of God. Yet Montemaggi argues for the Commedia as theology because it "can help us deepen, enrich, and refine our understanding of what theology is or could be. From our contemporary perspective it makes sense-it can, indeed, be fruitful—-to refer to the Commedia as theology, as discourse and inquiry about God wishing to aid us in our comprehension of our relationship with, and in our journeying into the divine" (Montemaggi 2016, p. 63).

\section{Outlining the Course Design}

Over the course of the five-week unit on medieval theology, students meet twice weekly for a total of ten seventy-five-minute class sessions. Individual students are responsible for leading discussion on primary texts throughout the semester. They prepare a brief biographical overview of the author as well as discussion questions and small group activities for the class in consultation with 
me. That pattern continues during our work with Dante and the other medieval theologians. At the end of the unit, students produce a close reading of one canto in Paradiso that interacts with one or two of the theologians we have studied.

Given that framework, the ten sessions move through a reading of Paradiso, often paired with readings from medieval theologians. As much as possible, I use readings in the assigned collection of primary texts, but I also provide supplemental readings as needed. The following discussion provides a sketch of those pairings for some of the class sessions.

Before our initial meeting, for example, students read the first three cantos alongside selections from Augustine's Confessions, including the opening paragraphs and selections on time and eternity, as well as from Pseudo-Dionysius's The Mystical Theology (Kerr 1990, pp. 52-60, 64-65; Baxter 2018, pp. 123-33, 139-44; Pseudo-Dionysius 1987, pp. 133-41). These readings lead them to a deeper understanding of the ineffability of God and Dante's inability to describe his heavenly vision fully (Par. 1.1-36). For the second meeting, students read selections from Augustine on free will and predestination to engage those themes in Paradiso 4 and 5 as Beatrice answers Dante's questions about the broken vows of Piccarda and Constance (Kerr 1990, pp. 61-62).

The third meeting features readings from Anselm and Abelard on atonement that pair with Beatrice's explanation of the way of redemption in Paradiso 7-a composite of the positions of Anselm and Thomas Aquinas (Kerr 1990, pp. 82-95; Hawkins 2006, p. 109). This canto also frames a broader discussion of divine love in Dante. As Peter Hawkins argues, this material provides a clear example of Dante's work as a theological teacher, as he presents the tradition through the words of Beatrice, offers a survey of possible understandings, and selects one theological position among others (Hawkins 2006, p. 109).

In the fourth meeting, readings from Thomas Aquinas and Francis of Assisi pair with Paradiso 10-12, where Dante the pilgrim hears the story of St. Francis from the Dominican St. Thomas and that of St. Dominic from the Franciscan St. Bonaventure (Kerr 1990, pp. 101-19). This pairing provides students with the opportunity to grasp differences between these two founders of competing religious orders but also to see how Dante's use of metaphor underscores their commonalities, creating two encircling wreaths of souls that even include Aquinas's archenemy, Siger of Brabant. Dante's heaven, as Jason Baxter observes, is a vibrant unity of song and dance that nonetheless contains "an uncompromising diversity and plurality" (Baxter 2018, p. 160).

Many of the later class meetings focus almost exclusively on Paradiso, and students work collaboratively in class to understand what their reading of Dante is teaching them about theology. Dante's theological examination in Paradiso 24, 25, and 26, for example, provides an occasion for reflection on the theological virtues. But the last class meeting returns to the pattern of pairing Paradiso with readings from other theologians: the final cantos of Paradiso lend themselves to the comparison of Dante's account with other mystical visions, like those of Dante's final guide, Bernard of Clairvaux, as well as those of Catherine of Siena and Julian of Norwich (Kerr 1990, pp. 96-98, 125-30).

Instructors who have less time allotted for the unit on medieval theology can easily adapt this approach, since their students can still read some cantos of Paradiso alongside their study of particular theologians or topics. Pairing Paradiso 1 with a discussion of ineffability or Paradiso 7 with medieval discussions of atonement, for example, works well without the rest of the framework sketched above.

\section{Meeting Course Objectives}

This five-week unit on the Paradiso preserves the breadth of theological voices and significant doctrinal discussions that students would encounter reading select primary texts alongside a secondary history of Christian thought. The process helps students to gain an appreciation for the broad consensus of medieval theology that Dante often presents, but it also enables them to grasp a range of theological positions. On the pages of Paradiso, they can begin to approach theology as a conversation. They can begin to see that theology is a living tradition, so that in the words of Alistair McIntyre, it is "an historically extended, socially embodied argument" (McIntyre 1984, p. 222). Dante often brings 
different positions together on one page, modeling the work of the theologian in presenting alternatives and taking positions on various questions. Dante thus teaches students not only the ideas of theology but also something of the process of reflection and engagement with the theological tradition, providing a depth to the study of medieval theology other texts do not as easily convey.

Reading Dante in the history of theology also provides students with at least three ways to understand the interaction of theology and Western culture in a profound way through their encounter with Dante's "sacred poem" (Par. 25.1). First, any reader of the poem encounters Dante's capacious vision that reaches beyond theology to embrace all parts of life, from politics to erotic love to astronomy, all presented alongside the theological concepts with which Dante interacts. Theology is not a discipline removed from other spheres of life but integral to them-and reading Dante makes that clearer than other approaches to teaching the history of the tradition. Secondly, Dante's writing provides a crucial demonstration of the ways the Christian tradition shapes the West and is at the same time shaped by the culture, as he both receives and transforms the theological tradition he inherits. He affirms his beliefs in central theological tenets while at the same time putting his own stamp on them. As Peter Hawkins puts it, "he gave us a new account of everything old" (Hawkins 2006, p. 130). Finally, Dante provides an opportunity to examine the influence of theology on Western culture through an examination of what Hawkins has called "his afterlife". Hawkins traces Dante's influence on the subsequent literary tradition, including Geoffrey Chaucer, John Milton, John Keats, Percy Bysshe Shelley, Lord Byron, Henry Wadsworth Longfellow, and Seamus Heaney, among others. Dante's influence on the tradition of visual arts is equally extensive, ranging from William Blake to Joshua Reynolds to Dante Gabriel Rossetti (Hawkins, p. 137-50). Similarly, Joan Acocella underscores the influence of Dante on composers-Franz Liszt's Dante Symphony and Pyotr Illich Tchaikovsky's Francesca da Rimini: Symphonic Fantasy after Dante, Op. 32 (Acocella 2013). For some class sessions, I have students listen to parts of these compositions or read short extracts of poems where Dante's influence appears. Dante's afterlife continues even in more contemporary cultural expressions. Hawkins also notes Dante's influence on the New Yorker cartoons of Robert Mankoff and Edward Frascino and the comics of Gary Panter, as well as a variety of films and television shows (Hawkins 2006, pp. 131-37, 150-53, 159-63). Other authors like Rod Dreher make the case that reading Dante provides wisdom for shaping contemporary lives (Dreher 2015).

These examples, along with others, indicate that students who read Paradiso find themselves better equipped to meet the course goal of understanding the interaction of theology and Western culture.

\section{Teaching Dante across the Curriculum}

This course redesign suggests a possible model for introducing students to Dante in the context of general education. The first step is for instructors to brainstorm about places where Dante might find a foothold in their institution's current general education curriculum, even in places where connections are not immediately apparent. Instructors might consider reading Dante in a survey course in Western civilization, or in medieval history or literature. Instructors might develop a literature course where students could trace his influence in literature and the arts. Courses that examine the themes of community or exiles and refugees—in the humanities or in political science-might find room for Dante as well.

Once instructors identify possible courses, they will need to consider ways Dante satisfies and enriches the goals that a specific course description sets out, preparing to make the case for Dante's inclusion as needed with departments or college curriculum committees and students. Beyond that, they will begin to develop specific plans for integrating Dante into their course, developing reading lists, planning activities, and crafting assignments. In taking up this task, instructors will enable students to stumble across the Commedia in expected and unexpected places. In so doing, they may help them to discover that this poem is, as one of my students put it, a living text. In reading and discussing Dante, they—both instructors and students—may find themselves as well among the lucky ones, among the blessed. 
Funding: This research received no external funding.

Conflicts of Interest: The author declares no conflict of interest.

\section{References}

Acocella, Joan. 2013. What the Hell: Dante in Translation and Dan Brown's New Novel. The New Yorker, May 27. Baranski, Zygmunt G. 2013a. (Un)orthodox Dante. In Reviewing Dante's Theology. Edited by Claire E. Honess and Matthew Treherne. Bern: Peter Lang, vol. 2, pp. 253-330.

Baranski, Zygmunt G. 2013b. Dante and Doctrine (and Theology). In Reviewing Dante's Theology. Edited by Claire E. Honess and Matthew Treherne. Bern: Peter Lang, vol. 1, pp. 9-63.

Baxter, Jason M. 2018. A Beginner's Guide to Dante's Divine Comedy. Grand Rapids: Baker Academic.

Dreher, Rod. 2015. How Dante Can Save Your Live: The Life-Changing Wisdom of History's Greatest Poem. New York: Regan Arts.

Gonzalez, Justo L. 2014. A History of Christian Thought: In One Volume. Nashville: Abingdon.

Hawkins, Peter S. 2006. Dante: A Brief History. Malden: Blackwell.

Kerr, Hugh T. 1990. Readings in Christian Thought, 2nd ed. Nashville: Abingdon.

McGrath, Alister E. 2013. Historical Theology: An Introduction to the History of Christian Thought, 2nd ed. Malden: Wiley-Blackwell.

McGrath, Alister E. 2016. The Christian Theology Reader, 5nd ed. Hoboken: Wiley.

McIntyre, Alasdair. 1984. After Virtue: A Study in Moral Theory, 2nd ed. Notre Dame: University of Notre Dame Press. Montemaggi, Vittorio. 2016. Reading Dante's Commedia as Theology: Divinity Realized in Human Encounter. New York: Oxford University Press.

Pseudo-Dionysius. 1987. Pseudo-Dionysius: The Complete Works. Translated by Colm Luibheid. New York: Paulist.

(C) 2019 by the author. Licensee MDPI, Basel, Switzerland. This article is an open access article distributed under the terms and conditions of the Creative Commons Attribution (CC BY) license (http://creativecommons.org/licenses/by/4.0/). 